Наливайко Т. Е., Гранина Н. М.

T. Ye. Nalivaiko, N. M. Granina

МОТИВАЦИЯ СТУДЕНТОВ ВУЗОВ К ИНФОРМАЦИОННО-ПОИСКОВОЙ ДЕЯТЕЛЬНОСТИ

\title{
UNIVERSITY STUDENT MOTIVATION TO RETRIEVAL ACTIVITY
}

Наливайко Татьяна Евгеньевна - доктор педагогических наук, профессор, проректор по учебновоспитательной работе Комсомольского-на-Амуре государственного технического университета (Россия, Комсомольск-на-Амуре); 681013, г. Комсомольск-на-Амуре, ул. Ленина, д. 27, 8-4217-53-98-25. E-mail: tenal@knastu.ru

Ms. Tatiana Ye. Nalivaiko - Doctor in Education, Professor, Vice-rector for Educational Work, Komsomolsk-onAmur State Technical University (Russia, Komsomolsk-on-Amur); 27 Lenin Str., Komsomolsk-on-Amur, zip code 681013, tel. 8-4217-53-98-25. E-mail: tenal@knastu.ru.

Гранина Наталья Михайловна - начальник подготовительного отделения Комсомольского-на-Амуре государственного технического университета (Россия, г. Комсомольск-на-Амуре); 681032, г. Комсомольскна-Амуре, ул. Вокзальная, д.70, кв. 55; тел.: 89142193622. E-mail: missisdea@mail.ru.

Ms. Natalia M. Granina - Head of the Preparatory Department, Komsomolsk-on-Amur State Technical University (Russia, Komsomolsk-on-Amur), 70, Vokzalnaya Str., apt. 55, Komsomolsk-on-Amur, zip code 681032, tel.: +79142193622. E-mail: missisdea@mail.ru.

Аннотация. В статье рассматривается информационно-поисковая деятельность студентов как компонент их информационной деятельности, обосновывается актуальность данного вида деятельности для профессионального становления будущего специалиста. Исследуется сущность информационно-поисковой деятельности. Раскрывается роль информационной мотивации при осуществлении информационного поиска.

Summary. The article deals with students' retrieval activities as part of their information activities, the urgency of this activity to become a specialist is focused on. The authors investigate the nature of retrieval activities and reveal the role of information motivation in retrieval activity.

Ключевые слова: информационная деятельность, информационно-поисковая деятельность, информационная система, поиск информации, имитационный компьютерный тренажер, информационная мотивация.

Key words: information activity, retrieval operations, information systems, information retrieval, computer simulator, information motivation.

УДК 378.1:004

Информационно-коммуникационные технологии прочно вошли во все сферы деятельности человека, в том числе в сферу образования. Информация в образовательной среде высших учебных заведений представлена большей частью в цифровом формате, а информационные источники объединены в электронные информационные массивы, доступ к которым возможен посредством технических средств (компьютеров, планшетов, сотовых телефонов). Эти условия повлекли за собой изменение требований к подготовке студентов в области взаимодействия с информацией: современный студент должен иметь доступ к различным информационным источникам, в том числе и электронным, уметь пользоваться этими источниками и извлекать из них нужную информацию, иметь навыки использования в своей деятельности технических средств получения, обработки и хранения информации. Для успешной учебной деятельности студентам необходимо уметь своевременно находить необходимую информацию и быстро, и качественно обрабатывать большие информационные объемы. В сложившихся условиях информационная деятельность студентов становится преобладающей. 
Пусковым механизмом, побуждающим субъекта к информационной деятельности, являются информационные потребности. Для успешной информационной деятельности, как отмечают исследователи, занимающиеся данной проблематикой, студентам необходимо осознавать свои информационные потребности и иметь положительную мотивацию.

В психологии потребность понимается как состояние индивида, создаваемое испытываемой им нуждой в объектах, необходимых для его существования и развития, и выступающее источником его активности. Потребность выступает как такое состояние личности, благодаря которому осуществляется регулирование поведения, определяется направленность мышления, чувств и воли человека [1]. Потребность представляет собой противоречие между чем-то необходимым и имеющимся у человека и выступает движущей силой деятельности. Информационные потребности представляют собой противоречие между имеющейся информацией (знаниями) и недостающей для решения какой-либо проблемы или задачи.

Потребности в информации, как выделяет в своем исследовании Лютикова Т.П., могут быть постоянными и эпизодическими, главными и второстепенными, осознанными и неосознанными, в зависимости от чего они по-разному понимаются и удовлетворяются субъектом деятельности [2]. Чтобы информационная деятельность была продуктивной и способствовала развитию информационной культуры личности, информационные потребности должны быть осознаваемы субъектом деятельности. Именно осознание собственных информационных потребностей приводит человека к поиску путей их удовлетворения, то есть к появлению информационной мотивации, которая представляет собой внутренние побуждения субъекта к информационной деятельности, вызывающие его активность и определяющие направленность самой деятельности.

В психологии мотивация понимается как совокупность внешних и внутренних условий, которые побуждают субъекта к активности, а также предмет или объект, на которых эта активность распространяется [2]. В социологии мотивацию рассматривают как осознаваемую потребность человека достигнуть определенных благ или определенных условий деятельности.

Информационная мотивация, по мнению Новиковой В.А., характеризует меру стремления субъекта к информационной деятельности, степень осознания собственных информационных потребностей в учебно-профессиональной деятельности и способности реализовывать их в образовательном процессе и вне его [3].

Информационная мотивация имеет следующие особенности:

- процесс мотивации тесно взаимосвязан с развитием основных функций мозга: с одной стороны, процессы мышления и памяти зависят от уровня мотивации, с другой стороны, на формирование мотивации оказывает прямое влияние уровень развития основных функций мозга;

- важным условием для формирования мотивации является создание обстановки психологического комфорта. Воспринимая информацию, человек не только осознает ее, но и выражает свое к ней отношение. Информация способна вызвать у человека различные эмоции: удивление, радость, отрицание и т.д. Можно сделать вывод, что эмоциональное сопровождение информационной деятельности повышает интерес студентов, стимулирует их познавательную активность и мотивацию.

Важной составляющей и залогом успеха информационной деятельности студентов является владение способами информационного поиска, т.е. владение способами отыскания в каком-либо подмножестве документов тех, которые соответствуют информационному запросу или содержат необходимые студенту факты или сведения, а также владение способами обработки и представления информации. В связи с чем в структуре информационной деятельности студентов выделяется информационно-поисковая деятельность, которая отражает уровень информационной компетентности студента и является основным фактором ее развития. Отличительной особенностью информационно-поисковой деятельности является ее организация, которая носит целенаправленный характер: студент осознает потребность в получении информации, которая побуждает его искать способ получения необходимой информации, при этом он понимает, для чего он выполняет те или иные действия по поиску (видит цель деятельности) и осознает, что он планирует получить в результате этих действий. Специфические действия по поиску информации направлены на соотне- 


\begin{tabular}{|c|c|c|}
\hline & & Ученые записқи № 밀(27) \\
\hline
\end{tabular}

сение образа искомого с поисковыми описаниями информационных объектов, входящих в состав информационного ресурса или системы. Конечной целью информационно-поисковой деятельности студентов выступает возможность извлечь из информации необходимые знания.

В качестве внешнего средства информационно-поисковой деятельности выступают системы поиска информации. Поисковые системы электронных источников информации и информационных систем имеют, с одной стороны, индивидуальный, отличный от других систем, пользовательский дизайн, с другой стороны, общие элементы организации механизма поиска: простой (поиск по одному условию) и расширенный поиск (возможность задать параметры поиска в зависимости от определенных условий). В результате информационно-поисковой деятельности студент получает результат, который соответствует или не соответствует поисковому запросу. Поэтому эффективность поиска во многом зависит от психологических особенностей студентов, от того, как протекает их взаимодействие с информационной системой, посредством которой происходит процесс отыскания необходимой информации, от особенностей организации ее системы поиска и от умения студента выполнять поисковый запрос в данной системе.

При отсутствии у студента понимания принципов функционирования поисковой системы информационного ресурса, у него появляются трудности в выполнении поискового запроса. Это приводит к потере интереса по взаимодействию с данной информационной системой и снижению мотивации к информационно-поисковой деятельности в целом. Студент испытывает дискомфорт, у него появляются эмоции отрицания использования данной информационной системы. Поэтому для подготовки к информационно-поисковой деятельности возникает необходимость научить студентов поиску информации в информационных системах с объяснением принципа организации данных и функционирования поискового механизма таких систем. Инструментом обучения работе с информационными системами могут выступать имитационные компьютерные тренажеры, позволяющие в удобное время и в удобном для себя режиме студентам овладеть основами информационно-поисковой деятельности на примере определенного информационного ресурса. Использование активных методов обучения, к которым относится применение в образовательном процессе имитационных компьютерных тренажеров:

- позволяет развивать информационное мышление студентов;

- способствует вовлечению студентов в решение информационно-поисковых задач, максимально приближенных к реальным ситуациям;

- расширяет и углубляет знания из области взаимодействия с информацией;

- развивает практические навыки и умения информационно-поисковой деятельности;

- повышает мотивацию студентов к данному виду деятельности.

\section{ЛИТЕРАТУРА}

1. Психологический словарь // Мир психологии. URL: http:/psychology.net.ru/dictionaries/ psy.html?word=697 (дата обращения: 13.06.2016).

2. Лютикова, Т. П. Развитие информационной культуры личности в образовательном процессе вуза: дис. ... канд. пед. наук / Т. П. Лютикова. - Ставрополь, 2006. - URL: http://www.diss.rsl.ru (дата обращения: 20.03.2011). - Заглавие с экрана.

3. Новикова, В. А. Информационно-образовательное пространство вуза как фактор формирования информационной профессиональной культуры будущего специалиста: дис. ... канд. пед. наук / В. А. Новикова. Рязань, 2009. URL: http://www.diss.rsl.ru (дата обращения: 20.03.2011). - Заглавие с экрана. 